\title{
The effects of bisphosphonates on osteoporotic patients after lumbar fusion: a meta-analysis
}

This article was published in the following Dove Press journal:

Drug Design, Development and Therapy

\author{
Wen-bin Liu',** \\ Wen-tao Zhao ${ }^{2, *}$ \\ Peng Shen ${ }^{3}$ \\ Fu-jiang Zhang' \\ 'Department of Joint Surgery, Tianjin \\ Hospital, Tianjin 3002II, People's \\ Republic of China; ${ }^{2}$ Department of \\ Orthopedics, The First Affiliated \\ Hospital of Yunnan Traditional \\ Chinese Medical University, Yunnan \\ 65002 I, People's Republic of China; \\ ${ }^{3}$ Department of Rheumatology and \\ Immunology, Tianjin First Center \\ Hospital, Tianjin 300192, People's \\ Republic of China \\ *These authors contributed equally \\ to this work
}

Purpose: We conducted a meta-analysis of controlled clinical trials to evaluate the efficacy of bisphosphonates in lumbar fusion.

Introduction: Bisphosphonates reduce bone resorption and remodeling by osteoclast activity inhibition, inactivation, and apoptosis. However, it remains controversial whether bisphosphonate therapy affects spinal fusion.

Methods: We searched MEDLINE, Cochrane CENTRAL, ScienceDirect, EMBASE, and Google Scholar to identify studies reporting the effects of bisphosphonates on osteoporotic patients after lumbar fusion. Secondary sources were identified from the references of the included literature. Pooled data were analyzed using RevMan 5.1.

Results: Seven studies met the inclusion criteria. There were significant differences in solid intervertebral fusion ( $\mathrm{RD}=0.07,95 \% \mathrm{CI}$ : -0.00 to $0.15, P=0.05)$, subsequent VCFs $(\mathrm{RD}=-0.21$, 95\% CI: -0.30 to $-0.12, P<0.00001)$, pedicle screw loosening ( $\mathrm{RD}=-0.17,95 \% \mathrm{CI}:-0.28$ to $-0.05, P=0.006)$, and cage subsidence ( $\mathrm{RD}=-0.25,95 \% \mathrm{CI}:-0.42$ to $-0.07, P=0.005)$ between two groups. No significant differences between two groups were found regarding implant fixation failure ( $\mathrm{RD}=-0.06,95 \% \mathrm{CI}:-0.22$ to $0.10, P=0.48$ ).

Conclusion: This meta-analysis showed that bisphosphonates may increase solid intervertebral fusion and decrease subsequent VCFs, pedicle screw loosening, and cage subsidence.

Keywords: bisphosphonates, lumbar, fusion, meta-analysis

\section{Introduction}

Lumbar fusion surgery is a common treatment approach for patients suffering from lumbar instability, trauma, and deformity. ${ }^{1}$ However, a previous study reported that these patients are more likely than other patients to have osteoporosis, ${ }^{2}$ and an increased prevalence of bone mineral loss has been observed in patients who underwent lumbar fusion surgery. ${ }^{3}$ As osteoporosis can result in spinal fusion failure, implant fixation failure, and vertebral compression fractures (VCFs) around fusion sites, ${ }^{4}$ the application of anti-osteoporosis agents may improve outcomes in patients treated with spinal fusion and instrumentation.

Bisphosphonates, first-line anti-osteoporotic drugs that have been approved for bone loss prevention and increasing bone quality and density, act by inhibiting osteoclastmediated bone resorption. ${ }^{5}$ However, extensive inhibition of bone resorption may lead to disruptions in the balance between osteoclastic and osteoblastic activities, with effects on bone graft healing. ${ }^{6}$ Previous animal studies have shown that bisphosphonates increase the size and density of fusion masses $^{7,8}$ and enhance fusion rates ${ }^{9}$ and bonescrew interface fixation after pedicle screw placement in spinal fusion. ${ }^{10}$ Recently, several human clinical studies have reported treatment outcomes of bisphosphonates
Correspondence: Fu-jiang Zhang Department of Joint Surgery, Tianjin Hospital, No 406 Jiefangnan Road, Tianjin 3002 II, People's Republic of China Tel +86 I 36 I2030606 Fax +8622 28332917

Email tjyyzfj@I26.com 
in lumbar fusion, ${ }^{11-16}$ though the results are contradictory. Moreover, methodological flaws in the published literature include poor study designs, small sample sizes, and variable outcomes. Therefore, we conducted a meta-analysis on the pooled results of randomized controlled trials (RCTs) and non-RCTs to evaluate the efficiency of bisphosphonates in lumbar fusion.

\section{Methods}

\section{Search strategy}

Electronic literature searches were performed in MEDLINE, Cochrane CENTRAL, ScienceDirect, EMBASE, and Google Scholar for articles published from 1966 to October 2017. Secondary sources were identified from studies cited in the references of retrieved articles. No studies were excluded based on language. The key search terms applied were "bisphosphonate", "lumbar", and "fusion" in combination with the Boolean operators AND or OR.

\section{Selection criteria and quality assessment}

The present meta-analysis included published RCTs and non-RCTs that compared a bisphosphonate with a control (placebo or null) in patients undergoing lumbar fusion. Two independent reviewers determined the suitability of the articles. A third reviewer resolved disagreements. Quality assessment for the RCTs was conducted according to a modification of the generic evaluation tool described in the Cochrane Handbook for Systematic Review of Interventions. ${ }^{17}$ The Methodological Index for Non-randomized Studies (MINORS) form was used to assess retrospective controlled trials. ${ }^{18}$

\section{Data extraction}

Data were extracted from the included studies by two independent researchers. In cases of incomplete data, the corresponding author of the study was contacted for additional information. The following information was extracted: the first author's name, publication year, interventions, outcome measures, sample size, and comparable baselines. Other relevant parameters were also extracted from the individual studies.

\section{Data analysis and statistical methods}

RevMan 5.1 (The Cochrane Collaboration, Oxford, UK) was used for analyzing pooled data. Heterogeneity was estimated by the $P$ - and $I^{2}$-values based on the standard chi-squared test. If significant heterogeneity was detected $\left(I^{2}>50 \%, P<0.1\right)$, a random-effects model was used for data analysis, whereas a fixed-effects model was used when no significant heterogeneity was found $\left(I^{2}<50 \%\right.$, $P>0.1$ ). In cases of significant heterogeneity, subgroup analysis was performed to investigate the sources. Mean differences and 95\% CI were determined for continuous outcomes. Dichotomous data were calculated by risk differences (RDs) and 95\% CI.

\section{Results}

\section{Search results}

A total of 116 studies were identified as potentially relevant literature reports. By scanning the titles and abstracts, 109 reports were excluded according to the eligibility criteria. No additional studies were obtained after the reference review. Ultimately, three RCTs and four non-RCTs were eligible for data extraction and meta-analysis. ${ }^{11-16,19,20}$ The search process is shown in Figure 1.

\section{Risk of bias assessment}

RCT quality was assessed based on the Cochrane Handbook for Systematic Review of Interventions (Figure 2). RCTs stated the clear inclusion and exclusion criteria. Included RCTs employed an adequate method of randomization, concealment of allocation, blinding, and intent-to-treat analysis. No unclear bias due to incomplete outcome data or selective outcomes was reported. For non-RCTs, MINORS scores were 18-20 for retrospectively controlled trials. The methodological quality assessment process is illustrated in Table 1.

\section{Study characteristics}

Demographic characteristics and details concerning the types of literature of the included studies are summarized in Table 2. Statistically similar baseline characteristics were observed between the groups.

\section{Outcomes of meta-analysis}

\section{Solid intervertebral fusion}

Solid intervertebral fusion was involved in six studies. ${ }^{11,13-16,19}$ No significant heterogeneity was found, and a fixed-effects model was applied $\left(I^{2}=26 \%, P=0.24\right)$. Solid intervertebral fusion in the bisphosphonate group was significantly higher than that in the control group $(\mathrm{RD}=0.07,95 \% \mathrm{CI}:-0.00$ to $0.15, P=0.05$; Figure 3 ).

\section{Subsequent VCFs}

Subsequent VCFs were assessed in four studies. ${ }^{11,15,16,19}$ As no significant heterogeneity was found, a fixed-effects 


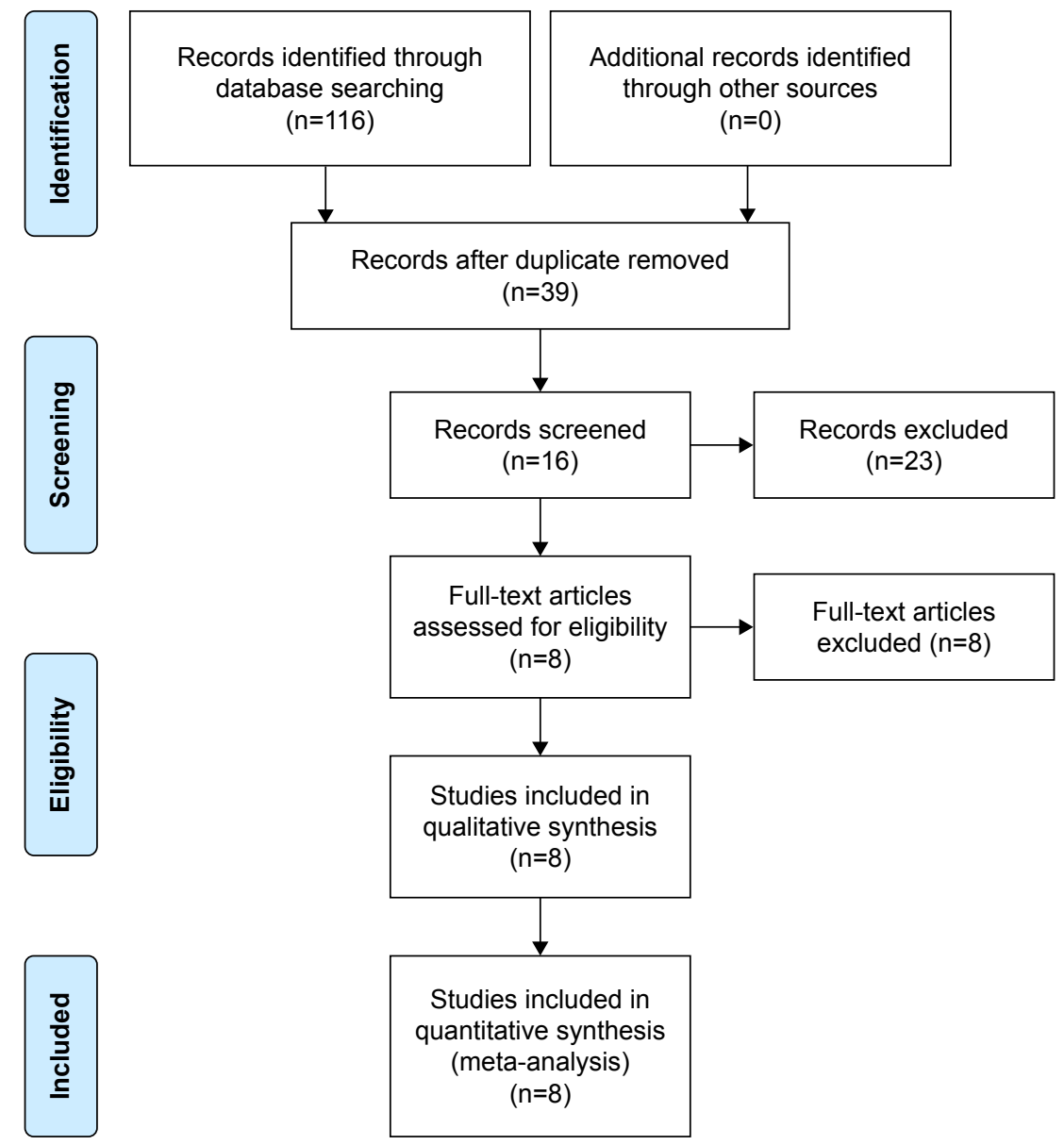

Figure I Flowchart of the study selection process.

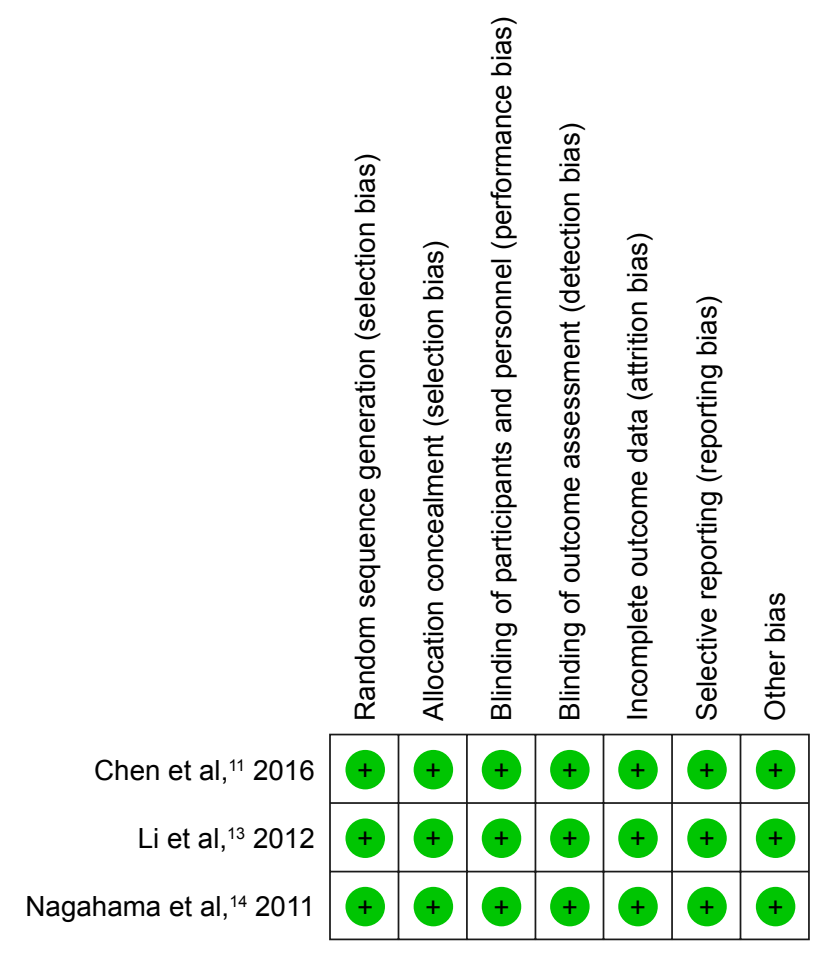

Figure 2 Risk of bias summary. Note: green+ indicates low risk. model was used $\left(I^{2}=0 \%, P=0.51\right)$. Subsequent VCFs in the bisphosphonate group were significantly lower than those in the control group ( $\mathrm{RD}=-0.21,95 \% \mathrm{CI}:-0.30$ to -0.12 , $P<0.00001$; Figure 4).

\section{Pedicle screw loosening}

Data on pedicle screw loosening were available in three studies. ${ }^{16,19,20}$ A fixed-effects model was applied because no significant heterogeneity was found $\left(I^{2}=0 \%, P=0.43\right)$. Overall, the incidence of pedicle screw loosening in the bisphosphonate group was significantly lower than that in the control group ( $\mathrm{RD}=-0.17,95 \% \mathrm{CI}:-0.28$ to -0.05 , $P=0.006$; Figure 5).

\section{Implant fixation failure}

Implant fixation failure was reported in two studies. ${ }^{11,15}$ No significant heterogeneity was found; thus, a fixed-effects model was utilized ( $\left.I^{2}=0 \%, P=1.00\right)$. There was no significant difference between the two groups regarding implant fixation failure ( $\mathrm{RD}=0.00,95 \% \mathrm{CI}:-0.05$ to $0.05, P=1.00$; Figure 6). 
Table I Quality assessment for non-randomized trials

\begin{tabular}{|c|c|c|c|c|c|}
\hline Quality assessment for non-randomized trials & $\begin{array}{l}\text { Ding et al, }{ }^{19} \\
2017\end{array}$ & $\begin{array}{l}\text { Kim et al, } \\
2014\end{array}$ & $\begin{array}{l}\text { Ohtori et al, }{ }^{20} \\
2013\end{array}$ & $\begin{array}{l}\text { Park et al, }{ }^{15} \\
2013\end{array}$ & $\begin{array}{l}\text { Tu et al, }{ }^{16} \\
2014\end{array}$ \\
\hline A clearly stated aim & 2 & 2 & 2 & 2 & 2 \\
\hline Inclusion of consecutive patients & 2 & 2 & 2 & 2 & 2 \\
\hline Prospective data collection & 0 & 0 & 0 & 0 & 0 \\
\hline End points appropriate to the aim of the study & 2 & 2 & 2 & 2 & 2 \\
\hline Unbiased assessment of the study end point & 2 & 2 & 2 & 2 & 2 \\
\hline A follow-up period appropriate to the aims of study & 2 & 2 & 2 & 2 & 2 \\
\hline Less than $5 \%$ loss to follow-up & 0 & 2 & 2 & 0 & 2 \\
\hline Prospective calculation of the sample size & 0 & 0 & 0 & 0 & 0 \\
\hline An adequate control group & 2 & 2 & 2 & 2 & 2 \\
\hline Contemporary groups & 2 & 2 & 2 & 2 & 2 \\
\hline Baseline equivalence of groups & 2 & I & 2 & 2 & 2 \\
\hline Adequate statistical analyses & 2 & 2 & 2 & 2 & 2 \\
\hline Total score & 18 & 19 & 20 & 18 & 20 \\
\hline
\end{tabular}

\section{Cage subsidence}

Two studies involved cage subsidence. ${ }^{14,16}$ Because no significant heterogeneity was found, a fixed-effects model was applied $\left(I^{2}=0 \%, P=0.96\right)$. The incidence of cage subsidence in the bisphosphonate group was significantly lower than that in the control group ( $\mathrm{RD}=-0.25,95 \% \mathrm{CI}$ : -0.42 to -0.07 , $P=0.005$; Figure 7).

\section{Discussion}

The most important finding of the present meta-analysis, including three RCTs and three non-RCTs, was that bisphosphonates promote lumbar intervertebral fusion and reduce subsequent $\mathrm{VCFs}$, pedicle screw loosening, and cage subsidence. To the best of our knowledge, our meta-analysis is the first quantitative study to evaluate the effects of bisphosphonates on human lumbar fusion.

Bisphosphonates reduce bone resorption and remodeling via inhibition of osteoclast activity, osteoclast inactivation, and osteoclast apoptosis. ${ }^{5}$ However, broad inhibition of bone resorption may reduce bone formation and lead to disruptions in the balance between osteoclastic and osteoblastic activities. ${ }^{6}$ Despite the controversy regarding whether bisphosphonate therapy affects spinal fusion, the present metaanalysis revealed that bisphosphonates improve the lumbar fusion rate $(\mathrm{RD}=0.03, P=0.05)$. This finding is consistent with those of three of the included studies. ${ }^{11,14,16}$ In a retrospective

Table 2 Characteristics of included studies

\begin{tabular}{|c|c|c|c|c|c|c|c|c|}
\hline Study & $\begin{array}{l}\text { Simple } \\
\text { size }(B / C)\end{array}$ & $\begin{array}{l}\text { Mean age } \\
(\mathrm{B} / \mathrm{C})\end{array}$ & $\begin{array}{l}\text { Female } \\
(\mathrm{B} / \mathrm{C})\end{array}$ & Drug & Duration & $\begin{array}{l}\text { Type of } \\
\text { fusion }\end{array}$ & $\begin{array}{l}\text { Assessment } \\
\text { of fusion }\end{array}$ & $\begin{array}{l}\text { Follow-up } \\
\text { (months) }\end{array}$ \\
\hline Chen et al,"' 2016 & $33 / 36$ & $65 / 63$ & $27 / 29$ & $\begin{array}{l}\text { Zoledronic } \\
\text { acid, } 5 \mathrm{mg}\end{array}$ & $\begin{array}{l}\text { One time infusion } \\
3 \text { days after surgery }\end{array}$ & PLIF & $\mathrm{Rx}, \mathrm{CT}$ & 12 \\
\hline Ding et al, ${ }^{19} 2017$ & $30 / 34$ & $64 / 66$ & $27 / 30$ & $\begin{array}{l}\text { Zoledronic } \\
\text { acid, } 5 \mathrm{mg}\end{array}$ & $\begin{array}{l}\text { One time infusion } \\
3-5 \text { days after surgery }\end{array}$ & TLIF & $\mathrm{Rx}, \mathrm{CT}$ & 24 \\
\hline Kim et al, ${ }^{12} 2014$ & 44 & 64.7 & 35 & $\begin{array}{l}\text { Alendronate, } \\
35 \mathrm{mg} / \text { week }\end{array}$ & NS & PLF & $\mathrm{Rx}$ & 33.8 \\
\hline Li et al, ${ }^{13} 2012$ & $4 \mid / 4 I$ & $63 / 63$ & $28 / 25$ & $\begin{array}{l}\text { Zoledronic } \\
\text { acid, } 5 \mathrm{mg}\end{array}$ & $\begin{array}{l}\text { One time infusion } \\
3 \text { days after surgery }\end{array}$ & TLIF & CT & 12 \\
\hline Nagahama et al, ${ }^{14} 2011$ & $19 / 17$ & $70 / 67$ & $18 / 16$ & $\begin{array}{l}\text { Alendronate, } \\
35 \text { mg/week }\end{array}$ & $\begin{array}{l}\text { Started I week after } \\
\text { surgery and continued } \\
\text { for } 12 \text { months }\end{array}$ & PLIF & $\mathrm{Rx}, \mathrm{CT}$ & 12 \\
\hline Ohtori et al, ${ }^{20} 2013$ & $20 / 22$ & $75 / 77$ & $20 / 22$ & $\begin{array}{l}\text { Risedronate } \\
2.5 \mathrm{mg} / \text { day }\end{array}$ & $\begin{array}{l}\text { Started } 2 \text { months } \\
\text { before and } 10 \text { months } \\
\text { after surgery }\end{array}$ & $\begin{array}{l}\text { Posterolateral } \\
\text { lumbar fusion }\end{array}$ & $\mathrm{Rx}, \mathrm{CT}$ & 12 \\
\hline Park et al, ${ }^{15} 2013$ & $22 / 22$ & $68 / 65$ & $17 / 13$ & $\begin{array}{l}\text { Zoledronic } \\
\text { acid, } 5 \text { mg }\end{array}$ & Single dose & $\begin{array}{l}\text { Posterolateral } \\
\text { lumbar fusion }\end{array}$ & $\mathrm{Rx}, \mathrm{CT}$ & 6 \\
\hline Tu et al, ${ }^{16} 2014$ & $32 / 32$ & $71 / 70$ & $27 / 26$ & $\begin{array}{l}\text { Zoledronic } \\
\text { acid, } 5 \mathrm{mg}\end{array}$ & $\begin{array}{l}3 \text { days postoperative, } \\
\text { then yearly }\end{array}$ & $\begin{array}{l}\text { Lumbar interbody } \\
\text { fusion }\end{array}$ & $\mathrm{Rx}$ & 24 \\
\hline
\end{tabular}

Abbreviations: B, bisphosphonate; C, control; CT, computed tomography; NS, not stated; PLF, posterior lumbar fusion; PLIF, posterior lumbar interbody fusion; Rx, X-ray; TLIF, transforaminal lumbar interbody fusion. 


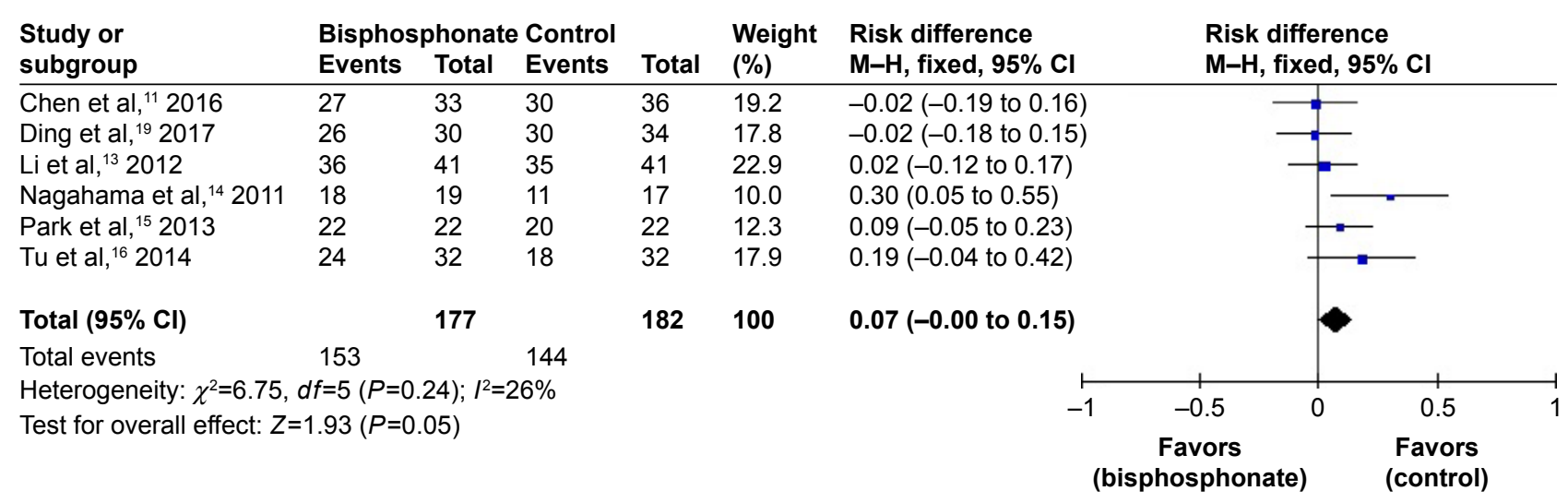

Figure 3 Forest plot of solid intervertebral fusion.

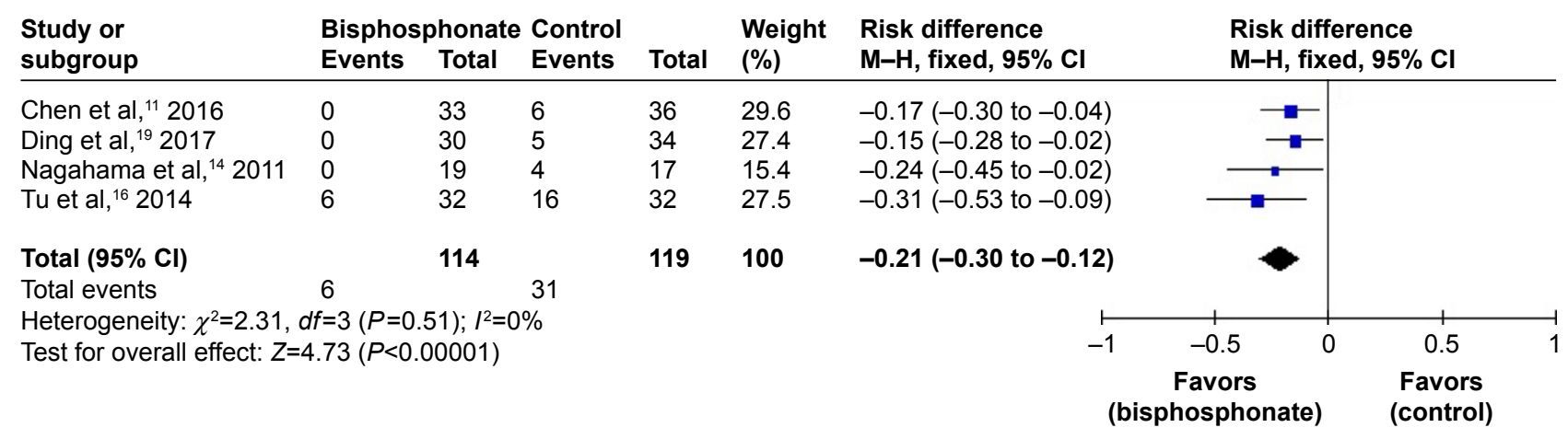

Figure 4 Forest plot of subsequent vertebral compression fractures.

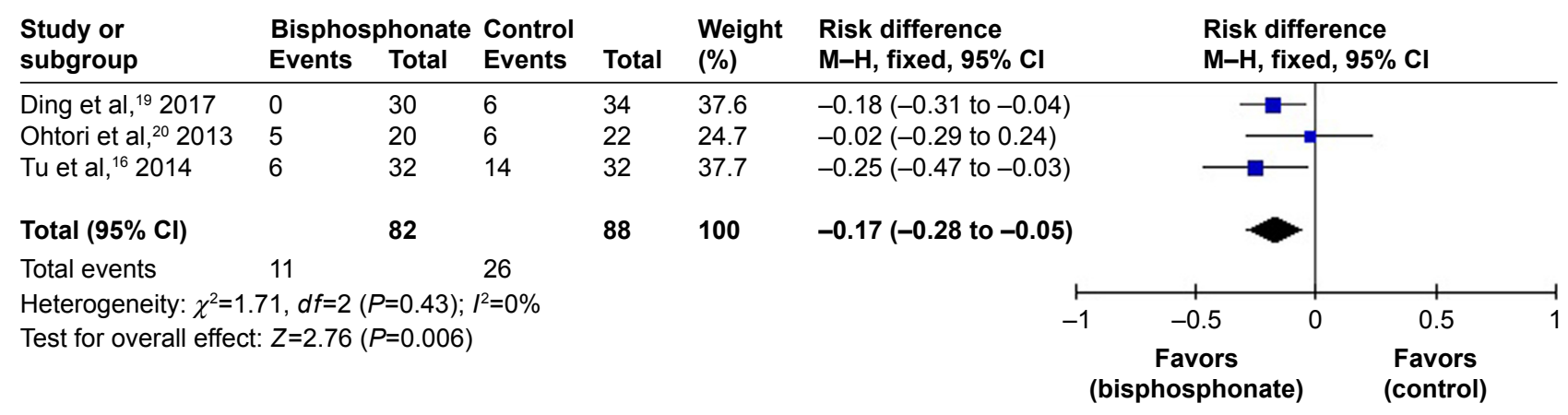

Figure 5 Forest plot of pedicle screw loosening.

\begin{tabular}{|c|c|c|c|c|c|c|c|c|}
\hline \multirow{2}{*}{$\begin{array}{l}\text { Study or } \\
\text { subgroup } \\
\text { Nagahama et al, }{ }^{14} 2011\end{array}$} & \multicolumn{2}{|c|}{$\begin{array}{l}\text { Bisphosphonate } \\
\text { Events Total }\end{array}$} & $\begin{array}{l}\text { Control } \\
\text { Events }\end{array}$ & Total & $\begin{array}{l}\text { Weight } \\
(\%)\end{array}$ & $\begin{array}{l}\text { Risk difference } \\
\mathrm{M}-\mathrm{H} \text {, fixed, } 95 \% \mathrm{CI}\end{array}$ & \multicolumn{2}{|c|}{$\begin{array}{l}\text { Risk difference } \\
\text { M-H, fixed, } 95 \% \mathrm{CI}\end{array}$} \\
\hline & 1 & 19 & 5 & 17 & 35.9 & $-0.24(-0.48$ to -0.00$)$ & & \\
\hline Tu et al, ${ }^{16} 2014$ & 9 & 32 & 17 & 32 & 64.1 & $-0.25(-0.48$ to -0.02$)$ & & \\
\hline Total $(95 \% \mathrm{Cl})$ & & 51 & & 49 & 100 & $-0.25(-0.42$ to -0.07$)$ & & \\
\hline Total events & 10 & & 22 & & & & & \\
\hline \multirow{2}{*}{\multicolumn{4}{|c|}{$\begin{array}{l}\text { Heterogeneity: } \chi^{2}=0.00, d f=1(P=0.96) ; I^{2}=0 \% \\
\text { Test for overall effect: } Z=2.81(P=0.005)\end{array}$}} & & & $\begin{array}{r}\vdash \\
-1\end{array}$ & -0.5 & 0.5 \\
\hline & & & & & & & $\begin{array}{l}\text { Favors } \\
\text { losphonate) }\end{array}$ & $\begin{array}{l}\text { Favors } \\
\text { (control) }\end{array}$ \\
\hline
\end{tabular}

Figure 6 Forest plot of implant fixation failure. 


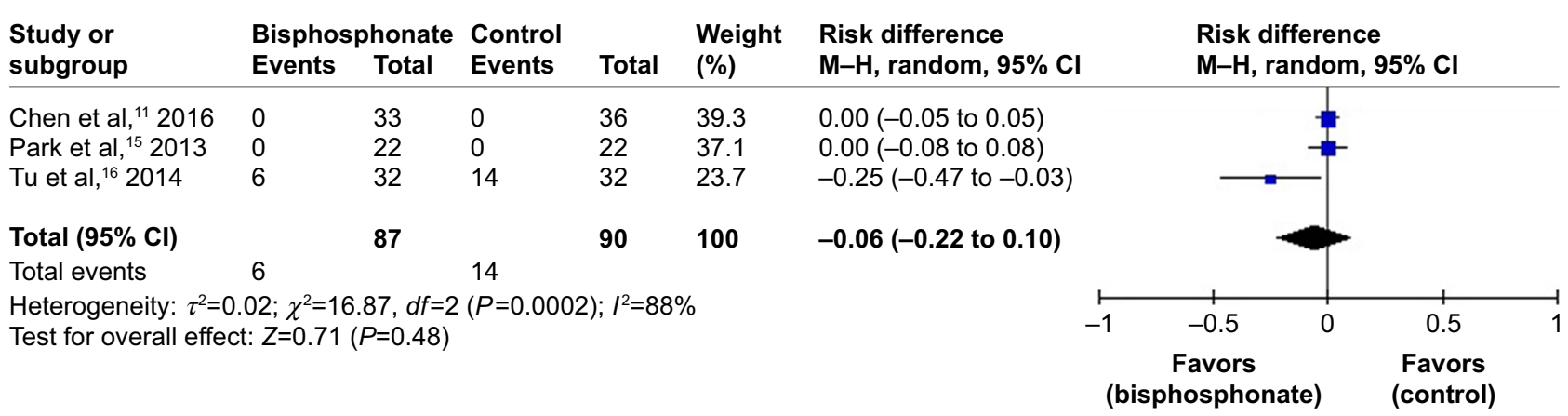

Figure 7 Forest plot of cage subsidence.

controlled study, Kim et al found that endplate degeneration decreases the fusion rate and that alendronate does not influence the fusion process. ${ }^{12}$

Three types of bisphosphonates were utilized among the included studies: zoledronic acid, alendronate, and risedronate in five, two, and one, respectively. Zoledronic acid was administered intravenously $5 \mathrm{mg}$ once on the third to fifth days after surgery, and the other bisphosphonates were applied for 1 year after surgery. Previous studies have demonstrated that zoledronic acid has higher binding capacity for hydroxyapatite and stronger anti-bone resorption effects compared with other bisphosphonates. ${ }^{21,22}$ A recent metaanalysis also showed that zoledronic acid is highly effective at reducing fractures. ${ }^{23}$ Regardless, there is no consensus on the timing of bisphosphonate application. Amanat et al found that in rat model, delayed single-dose infusion of zoledronic acid results in a larger and stronger callus than does immediate application at the time of the fracture. ${ }^{24}$ Conversely, Colon-Emeric et al reported that zoledronic acid infusion has no clinically evident effect on fracture healing ${ }^{25}$ and Einhorn concluded that fracture bone debris needs to be absorbed to allow space for new bone formation in compact bone. ${ }^{26}$ In contrast, with a large enough environment for cancellous new bone formation, the bone remodeling suppressed by a reduction in resorption due to bisphosphonate is not an important element. ${ }^{27}$

Failure of pedicle screw internal fixation is one of the crucial factors underlying nonunion after spinal fusion. Previous studies in animal models have found that bisphosphonates have an inhibitory effect on osteointegration around the implant. ${ }^{28,29}$ Xue et al used a porcine model to evaluate the influence of alendronate treatment on bone-pedicle screw interface fixation. ${ }^{10}$ These authors found that alendronate increased bone purchase of screw surfaces and can be an alternate approach for optimizing pedicle screw fixation. Previous clinical studies have also shown that bisphosphonates can decrease pedicle screw loosening by inhibiting bone resorption on the surface of screws. Pooled results suggest a significant difference in the incidence of pedicle screw loosening between the two groups ( $\mathrm{RD}=-0.17, P=0.006)$. Our results are consistent with these previous results.

Bisphosphonates have been found to significantly decrease the incidence of VCFs and to increase bone mineral density (BMD). ${ }^{30}$ In osteoporotic patients, cortical bone becomes thin and porous; trabecular bone also becomes thin, with simultaneous reduction in the amount of bone. Both result in increased risk of microfracture. In addition, Li et al found that rigid fusion after posterior lumbar interbody fusion increases stress and leads to a greater risk of adjacent VCFs in osteoporotic patients. ${ }^{31}$ Pooled data demonstrated a significant difference in the incidence of subsequent VCFs $(\mathrm{RD}=-0.24, P<0.001): 7.1 \%$ in patients receiving a bisphosphonate and $30.6 \%$ in controls. Thus, bisphosphonates prevent subsequent VCFs in patients with lumbar fusion.

Moreover, cage subsidence, defined as $>2 \mathrm{~mm}$ sinking of the cages, is a common complication of lumbar fusion surgery, and a higher rate of cage subsidence is more likely to be related to poor clinical outcomes. ${ }^{32}$ The present meta-analysis found that bisphosphonates decreased the incidence of cage subsidence $(\mathrm{RD}=-0.25, P=0.005)$. Several studies have shown that osteoporosis is a risk factor for cage subsidence. ${ }^{33,34}$ In addition, biomechanical studies have demonstrated that low BMD can weaken the endplate for load transfer and result in cage subsidence. ${ }^{35-37}$

Some potential limitations were noted in the present metaanalysis: 1) only six studies were identified, and the sample size of each trial was relatively small; 2) a methodological weakness exists in non-RCTs and should be considered when interpreting the findings of the present meta-analysis; and 3 ) some of the data were incomplete, and we were unable to conduct a meta-analysis on outcomes, such as the volume of drainage and functional scores. 


\section{Conclusion}

This meta-analysis of the current literature indicates that bisphosphonates can promote lumbar intervertebral fusion and reduce subsequent VCFs, pedicle screw loosening, and cage subsidence. Further high-quality studies are required to confirm our findings.

\section{Author contributions}

W-BL and F-JZ conducted the literature search and assessed the studies for exclusion or inclusion. W-BL and W-TZ extracted the data from the included studies, performed the meta-analysis, and drafted the manuscript. W-BL, PS, and F-JZ conceived the idea of the study, designed the study, and critically revised the manuscript for important intellectual content. All authors contributed toward data analysis, drafting and revising the paper and agree to be accountable for all aspects of the work.

\section{Disclosure}

The authors report no conflicts of interest in this work.

\section{References}

1. Harris BM, Hilibrand AS, Savas PE, et al. Transforaminal lumbar interbody fusion: the effect of various instrumentation techniques on the flexibility of the lumbar spine. Spine (Phila Pa 1976). 2004;29(4):E65-E70.

2. Wang YX, Deng M, Griffith JF, et al. Lumbar spondylolisthesis progression and de novo spondylolisthesis in elderly chinese men and women: a year-4 follow-up study. Spine (Phila Pa 1976). 2016;41(13): 1096-1103.

3. Chin DK, Park JY, Yoon YS, et al. Prevalence of osteoporosis in patients requiring spine surgery: incidence and significance of osteoporosis in spine disease. Osteoporos Int. 2007;18(9):1219-1224.

4. Greenspan SL, Maitland LA, Myers ER, Krasnow MB, Kido TH. Femoral bone loss progresses with age: a longitudinal study in women over age 65. J Bone Miner Res. 1994;9(12):1959-1965.

5. Russell RG, Watts NB, Ebetino FH, Rogers MJ. Mechanisms of action of bisphosphonates: similarities and differences and their potential influence on clinical efficacy. Osteoporos Int. 2008;19(6):733-759.

6. Schimmer RC, Bauss F. Effect of daily and intermittent use of ibandronate on bone mass and bone turnover in postmenopausal osteoporosis: a review of three phase II studies. Clin Ther. 2003;25(1):19-34.

7. Huang RC, Khan SN, Sandhu HS, et al. Alendronate inhibits spine fusion in a rat model. Spine (Phila Pa 1976). 2005;30(22):2516-2522.

8. Yasen M, Li X, Jiang L, Yuan W, Che W, Dong J. Effect of zoledronic acid on spinal fusion outcomes in an ovariectomized rat model of osteoporosis. J Orthop Res. 2015;33(9):1297-1304.

9. Bransford R, Goergens E, Briody J, Amanat N, Cree A, Little D. Effect of zoledronic acid in an L6-L7 rabbit spine fusion model. Eur Spine J. 2007;16(4):557-562

10. Xue Q, Li H, Zou X, et al. Alendronate treatment improves bone-pedicle screw interface fixation in posterior lateral spine fusion: an experimental study in a porcine model. Int Orthop. 2010;34(3):447-451.

11. Chen F, Dai Z, Kang Y, Lv G, Keller ET, Jiang Y. Effects of zoledronic acid on bone fusion in osteoporotic patients after lumbar fusion. Osteoporos Int. 2016;27(4):1469-1476.

12. Kim SM, Rhee W, Ha S, Lim JH, Jang IT. Influence of alendronate and endplate degeneration to single level posterior lumbar spinal interbody fusion. Korean J Spine. 2014;11(4):221-226.
13. Li C, Wang HR, Li XL, Zhou XG, Dong J. The relation between zoledronic acid infusion and interbody fusion in patients undergoing transforaminal lumbar interbody fusion surgery. Acta Neurochir (Wien). 2012;154(4):731-738

14. Nagahama K, Kanayama M, Togawa D, Hashimoto T, Minami A. Does alendronate disturb the healing process of posterior lumbar interbody fusion? A prospective randomized trial. J Neurosurg Spine. 2011;14(4):500-507.

15. Park YS, Kim HS, Baek SW, Kong DY, Ryu JA. The effect of zoledronic acid on the volume of the fusion-mass in lumbar spinal fusion. Clin Orthop Surg. 2013;5(4):292-297.

16. Tu CW, Huang KF, Hsu HT, Li HY, Yang SS, Chen YC. Zoledronic acid infusion for lumbar interbody fusion in osteoporosis. J Surg Res. 2014;192(1):112-116

17. Handoll HH, Gillespie WJ, Gillespie LD, Madhok R. The Cochrane Collaboration: a leading role in producing reliable evidence to inform healthcare decisions in musculoskeletal trauma and disorders. Indian J Orthop. 2008;42(3):247-251.

18. Slim K, Nini E, Forestier D, Kwiatkowski F, Panis Y, Chipponi J. Methodological index for non-randomized studies (MINORS): development and validation of a new instrument. ANZ J Surg. 2003;73(9):712-716.

19. Ding Q, Chen J, Fan J, Li Q, Yin G, Yu L. Effect of zoledronic acid on lumbar spinal fusion in osteoporotic patients. Eur Spine J. 2017; 26(11):2969-2977.

20. Ohtori S, Inoue G, Orita S, et al. Comparison of teriparatide and bisphosphonate treatment to reduce pedicle screw loosening after lumbar spinal fusion surgery in postmenopausal women with osteoporosis from a bone quality perspective. Spine (Phila Pa 1976). 2013;38(8):E487-E492.

21. Nancollas GH, Tang R, Phipps RJ, et al. Novel insights into actions of bisphosphonates on bone: differences in interactions with hydroxyapatite. Bone. 2006;38(5):617-627.

22. Dunford JE, Thompson K, Coxon FP, et al. Structure-activity relationships for inhibition of farnesyl diphosphate synthase in vitro and inhibition of bone resorption in vivo by nitrogen-containing bisphosphonates. J Pharmacol Exp Ther. 2001;296(2):235-242.

23. Zhou J, Ma X, Wang T, Zhai S. Comparative efficacy of bisphosphonates in short-term fracture prevention for primary osteoporosis: a systematic review with network meta-analyses. Osteoporos Int. 2016;27(11):3289-3300.

24. Amanat N, McDonald M, Godfrey C, Bilston L, Little D. Optimal timing of a single dose of zoledronic acid to increase strength in rat fracture repair. J Bone Miner Res. 2007;22(6):867-876.

25. Colon-Emeric C, Nordsletten L, Olson S, et al. Association between timing of zoledronic acid infusion and hip fracture healing. Osteoporos Int. 2011;22(8):2329-2336.

26. Einhorn TA. The cell and molecular biology of fracture healing. Clin Orthop Relat Res. 1998;(355 Supp1):S7-S21.

27. Gong HS, Song CH, Lee YH, Rhee SH, Lee HJ, Baek GH. Early initiation of bisphosphonate does not affect healing and outcomes of volar plate fixation of osteoporotic distal radial fractures. J Bone Joint Surg Am. 2012;94(19):1729-1736.

28. Hilding M, Ryd L, Toksvig-Larsen S, Aspenberg P. Clodronate prevents prosthetic migration: a randomized radiostereometric study of 50 total knee patients. Acta Orthop Scand. 2000;71(6):553-557.

29. Soininvaara TA, Jurvelin JS, Miettinen HJ, Suomalainen OT, Alhava EM, Kroger PJ. Effect of alendronate on periprosthetic bone loss after total knee arthroplasty: a one-year, randomized, controlled trial of 19 patients. Calcif Tissue Int. 2002;71(6):472-477.

30. Brown JP, Roux C, Ho PR, et al. Denosumab significantly increases bone mineral density and reduces bone turnover compared with monthly oral ibandronate and risedronate in postmenopausal women who remained at higher risk for fracture despite previous suboptimal treatment with an oral bisphosphonate. Osteoporos Int. 2014;25(7):1953-1961.

31. Li YC, Yang SC, Chen HS, Kao YH, Tu YK. Impact of lumbar instrumented circumferential fusion on the development of adjacent vertebral compression fracture. Bone Joint J. 2015;97-B(10):1411-1416. 
32. Jiya TU, Smit T, van Royen BJ, Mullender M. Posterior lumbar interbody fusion using non resorbable poly-ether-ether-ketone versus resorbable poly-L-lactide-co-D,L-lactide fusion devices. Clinical outcome at a minimum of 2-year follow-up. Eur Spine J. 2011;20(4):618-622.

33. Oh KW, Lee JH, Lee DY, Shim HJ. The correlation between cage subsidence, bone mineral density, and clinical results in posterior lumbar interbody fusion. Clin Spine Surg. 2017;30(6):E683-E689.

34. Chen Y, Chen D, Guo Y, et al. Subsidence of titanium mesh cage: a study based on 300 cases. J Spinal Disord Tech. 2008;21(7):489-492.
35. Hou Y, Yuan W. Influences of disc degeneration and bone mineral density on the structural properties of lumbar end plates. Spine J. 2012; 12(3):249-256.

36. Jost B, Cripton PA, Lund T, et al. Compressive strength of interbody cages in the lumbar spine: the effect of cage shape, posterior instrumentation and bone density. Eur Spine J. 1998;7(2):132-141.

37. Polikeit A, Ferguson SJ, Nolte LP, Orr TE. Factors influencing stresses in the lumbar spine after the insertion of intervertebral cages: finite element analysis. Eur Spine J. 2003;12(4):413-420.

\section{Publish your work in this journal}

Drug Design, Development and Therapy is an international, peerreviewed open-access journal that spans the spectrum of drug design and development through to clinical applications. Clinical outcomes, patient safety, and programs for the development and effective, safe, and sustained use of medicines are the features of the journal, which has also been accepted for indexing on PubMed Central. The manuscript management system is completely online and includes a very quick and fair peer-review system, which is all easy to use. Visit http://www.dovepress.com/testimonials.php to read real quotes from published authors.

Submit your manuscript here: http://www.dovepress.com/drug-design-development-and-therapy-journal 